\title{
INFLUENCE OF CONTEXTUAL TEACHING AND LEARNING (CTL) ON ABILITY OF STORY AND CONCEPT OF NUMBERS OF CHILDREN GROUP A
}

\author{
Y. Setiyowati \\ Taman Kanak-kanak (TK) Islam Al-Khasanah Gresik, Indonesia \\ Email :yeni_setyo@gmail.com
}

\begin{abstract}
This study aims to determine the influence of Contextual Teaching and Learning (CTL) on ability of story and concept of numbers of children group A. Approach research in this study is quantitative research with experimental model design or quasi experimental design. Data collection techniques used are observation and documentation. Data analysis technique used is paired t-test. Based on the results of the analysis it can be concluded: (1) there is a difference in the ability to tell the story between before (pretest) and after (posttest) get CTL in the experimental group, so that there is a significant influence on the use of CTL on ability of story; (2) there are differences in the concept of numbers between before (pretest) and after (posttest) getting CTLs in the experimental group, so that there is a significant influence on the use of CTL on concept of numbers of children group A.

Keywords: Contextual Teaching and Learning (CTL), Ability of Story and Concept, Children Group A.
\end{abstract}

Abstrak: Penelitian ini bertujuan untuk mengetahui pengaruh Contextual Teaching and Learning (CTL) terhadap kemampuan cerita dan konsep jumlah anak-anak kelompok A. Pendekatan penelitian dalam penelitian ini adalah penelitian kuantitatif dengan desain model eksperimen atau desain eksperimen semu. Teknik pengumpulan data yang digunakan adalah observasi dan dokumentasi. Teknik analisis data yang digunakan adalah paired t-test. Berdasarkan hasil analisis dapat disimpulkan: (1) ada perbedaan kemampuan bercerita antara sebelum (pretest) dan sesudah (posttest) mendapat CTL pada kelompok eksperimen, sehingga ada pengaruh yang signifikan tentang penggunaan CTL pada kemampuan cerita; (2) terdapat perbedaan konsep angka antara sebelum (pretest) dan sesudah (posttest) mendapatkan CTL pada kelompok eksperimen, sehingga terdapat pengaruh yang signifikan terhadap penggunaan CTL pada konsep jumlah anak kelompok A.

Kata kunci: Contextual Teaching and Learning (CTL), Kemampuan Cerita dan Konsep, Kelompok Anak A. 


\section{Introduction}

Contextual learning is a translation of Contextual Teaching and Learning (CTL) can be interpreted as a learning that is associated with a certain atmosphere (Johnson \& Johnson, 2002). CTL's approach is a learning concept that connects meaningfully between the material taught to the real-world situation of the child and encourages the knowledge it has with its application in the life of the child as a member of the family and community.

CTL is a learning that emphasizes the process of full student involvement to find material learned and relate to real-life situations (Johnson, 2002). According to Nurhadi (2002), the seven main components of CTL learning are constructivism, Inquiry, Questioning, Learning Community, Modeling, Reflection, Authentic Assessment.

CTL offers a path to academic excellence that all students can follow. This can happen because CTL fits the way the brain works and the principles that support the living system. Recent discoveries in modern science of the brain, and certain basic principles that underpin all living systems and the entire universe, form the basis for contextual learning and teaching.

Aspects of development that must be stimulated one of them is the cognitive aspect. Cognitive development is a process of thinking, namely the ability of individuals to connect, assess and consider an incident or event (Sujiono, 2010). The cognitive developmental aspect is important to develop because it has the goal of developing the child's ability so that it can find various problem solving alternatives, help the child to develop the ability of mathematical logic and knowledge of space and time (Depdiknas, 2007). The emergence of cognitive abilities in children is influenced by aspects of the child's brain maturity combined with giving children the opportunity to explore and enrich their experience (Santrock, 2009).

According to Aqib (2009) suggests cognitive development aims to: (a) develop the thinking ability of children to be able to manage their learning achievement, (b) to find various alternative solutions, (c) to help children develop their mathematical logic skills and knowledge of space and time, (D) have the ability to sort through, group, and (e) prepare for the development of the ability to think carefully.

According to Piaget (in Suparno, 2001) suggests that cognition is synonymous with the intellectual, because the intellectual process will relate to the concepts that children already possess and relate to how children use their thinking skills in solving problems. The thinking of children aged 4 to 7 years is growing very rapidly gradually towards conceptualization.

According to Montessori (in Sudono, 1995), playing with children has the ability to understand concepts and notions naturally without coercion such as the concept of numbers and the concept of color. Where is the way in improving the understanding of the concept of numbers in early childhood, especially in kindergarten children through CTL. CTL learning can link learning materials with real life in children.

Other causes are the ability to recognize the concept of numbers (for example: calling, counting and citing and grouping) is still low this is due to the method of learning in schools that often use the worksheet. The child activity only works on worksheets that contain cognitive development about counting, calculating, connecting numbers with letters, numbering numbers and matching numbers with number symbols.

It causes the child can't fully understand the concept of numbers and cognitive abilities of children will not develop optimally. The existence of difficulties faced by the child has an impact on the learning outcomes are not achieved optimally.

Learning CTL if associated with the scope of language development will be more meaningful and meaningless. The intended meaning is to foster interest in children's learning. The interest will grow if the child sees reality directly, not from the information obtained. 
Early childhood, especially 4-5 years old can develop amazing vocabulary. Owens (in Kurnia, 2009) suggests that "the children of that age enrich their vocabulary through repetition". They often repeat new and unique vocabulary even if they do not understand the meaning. Developing the vocabulary, the child uses fast wrapping is a process where the child absorbs the meaning of a new word after hearing it once or twice in the dialogue. It is at this early age that children begin to combine syllables into words, and words become sentences.

Based on the factual conditions in the field this learning is relevant and appropriate to be implemented using CTL as a learning that initially changed to traditional CTL. CTL learning is very suitable in applied in kindergarten especially on aspects of language and cognitive development. CTL will be more meaningful, if the child has experienced what he or she has learned, not knowing from others.

The formulation of the problem in this research is: is there any influence of CTL on the ability of story and the concept of number of children group A in Al Khasanah Gresik Islamic Kindergarten?

The purpose of this study is to determine the influence of learning CTL on the ability of story and the concept of the number of children group A in Al Khasanah Gresik Islamic Kindergarten.

\section{Research Methods}

The study was conducted using the experimental design or experimental model design, where this design has a control group but can't function fully to control the external variables that affect the experimental implementation. This study uses the Nonequivalent Control Group Design, where the experimental group and the control group are not selected randomly (Sugiyono, 2014).

In this experimental study, the researchers divide the two groups namely, the experimental group and the control group. Both groups have the same nature and characteristics. In the experimental group treated with CTL, while in the control group in traditional learning. Furthermore, the research process was observed to determine the differences that occurred in the experimental group.

Data analysis techniques used to process quantitative data in the form of numbers using t-test statistical analysis (paired t-test). This statistical analysis is used to determine whether there are differences in the ability to recognize the concept of numbers and the ability of vocabulary between before (pretest) and after (posttest) to get treatment (treatment) in the form of learning by using CTL. 


\section{Results and Discussion}

\section{Table 1}

Cognitive Difference (concept of numbers) between Before (pre-test) and After (post-test) Obtaining CTL

\begin{tabular}{|c|c|c|c|c|c|}
\hline Group & \multicolumn{2}{|c|}{ Mean } & $\begin{array}{c}\text { Mean } \\
\text { Differences }\end{array}$ & Sig. & Conclusion \\
\hline \multirow{2}{*}{ Experiment } & Pretest & 13.2273 & \multirow{2}{*}{-4.8636} & \multirow{2}{*}{0.000} & \multirow{2}{*}{$\begin{array}{l}\text { There is a } \\
\text { difference }\end{array}$} \\
\hline & Postest & 18.0909 & & & \\
\hline \multirow{2}{*}{ Control } & Pretest & 12.7273 & \multirow{2}{*}{-0.5000} & \multirow{2}{*}{0.178} & \multirow{2}{*}{$\begin{array}{c}\text { No } \\
\text { difference }\end{array}$} \\
\hline & Postest & 13.2273 & & & \\
\hline
\end{tabular}

Based on the result of different test with Paired t test, the value of Sig is 0.000 which is smaller than 0.05 , then reject hypothesis which means there is cognitive difference (concept of number) between before (pretest) and after (posttest) get CTL In the experimental group. While in the control group, obtained Sig value of 0.178 which is greater than 0.05 , then accept H1 and reject $\mathrm{H} 0$ which means there is no cognitive (concept of numbers) between before (pretest) and after (posttest) get CTL.

Looking at the mean score, cognitive (concept of numbers) after being given a CTL model learning is greater than cognitive (concept number) before being given a CTL model of learning that is 18.0909> 13.2273. This means that after being given a model of CTL learning on Al Khasanah Gresik Islamic Kindergarten students have a cognitive improvement (concept of number).

This supports the opinion of Sujiono (2010), cognitive development refers to the development of the child in terms of thinking and ability to provide a reason in which the cognitive is a process of thinking, ie the ability of individuals to connect, assess and consider an event or occurrence.

The result of the research shows that there are differences of the concept of numbers between before (pretest) and after (posttest) getting CTL, where the concept of number after being given CTL learning is higher than the concept of number before CTL learning. This means that the learning of CTL is needed in the concept of numbers about counting objects, recognizing, showing symbols of numbers, counting objects, grouping objects.

This is also reinforced by some research journals by the opinion of Luh Vienna (2016) explaining that CTL learning is associated with cognitive development and the concept of numbers in group $\mathrm{A}$ has a positive effect on learning in the classroom, as the opinion of $\mathrm{Ni}$ made (2014) also explains that learning CTL can improve Cognitive development of children in the classroom. Likewise with the opinion Kartika Rinakit Adhe explained that the application of learning CTL can provide good results for child cognitive development. 


\section{Table 2}

Differences Ability of Story between before (pre-test) and After (post-test)

\begin{tabular}{|c|c|c|c|c|c|}
\hline Group & \multicolumn{2}{|c|}{ Mean } & $\begin{array}{c}\text { Mean } \\
\text { Differences }\end{array}$ & Sig. & Conclusion \\
\hline \multirow{2}{*}{ Experiment } & Pretest & 7.8182 & \multirow{2}{*}{-1.36364} & \multirow{2}{*}{0.005} & \multirow{2}{*}{$\begin{array}{l}\text { There is a } \\
\text { difference }\end{array}$} \\
\hline & Postest & 9.1818 & & & \\
\hline \multirow{2}{*}{ Control } & Pretest & 9.0455 & \multirow{2}{*}{-0.40909} & \multirow{2}{*}{0.206} & \multirow{2}{*}{ No difference } \\
\hline & Postest & 9.4545 & & & \\
\hline
\end{tabular}

Based on the result of different test with paired t test, the value of Sig is 0.005 which this value is smaller than 0.05, then reject Hypotesis here is difference between ability of story before (pretest) and after (posttest) get CTL in experiment group. While in the control group, obtained Sig value of 0.206 which this value is greater than 0.05 , then accept hypothesis which means there is a difference in the ability of story between before (pretest) and after (posttest) get CTL in the control group.

By looking at the average score, the ability to tell stories after learning the CTL model is greater than the ability to write before CTL model learning is $9.18>7.82$. This means that after being given a model of CTL learning on Al Khasanah Gresik Islamic Kindergarten students there is an increase in the ability of story, where the increase is quite large, so that the statistical test showed a significant difference.

The above exposure is in line with Susanto's (2011) opinion that the development of very seated language skills occurs in children before the age of six. Children can get the language quickly once they start talking. It can be understood because the child uses the language and context used.

The results showed that there was a difference in the ability of storytelling between before (pretest) and after (posttest) to get CTL, where the ability to tell after CTL learning was higher than the ability to tell stories before being given a CTL lesson. This means that the learning of CTL is needed in the language lesson of mentioning the word symbolized in the symbols, composing the sentence, and completing the exact sentence with the word.

It is also reinforced by a research journal by Utami (2010) which explains that there is an influence on the ability to tell stories in the process of learning the development of language in the classroom. This is in line with the opinion Rahmatul (2016) the ability to tell stories in language development can be improved by using learning CTL. 


\section{Conclusions and Suggestions}

Based on the results of the analysis in the previous chapter can be concluded that: (1) There is the influence of CTL on cognitive development (concept of number) group A in Al Khasanah Gresik Islamic Kindergarten. It is known from the cognitive difference (concept of numbers) between before (pretest) and after (posttest) get CTL in the experimental group. Thus the first hypothesis of research that states "There is influence of CTL on cognitive development of group A in Al Khasanah Gresik Islamic Kindergarten" proved its. The cognitive development (concept of numbers) after being given CTL learning is higher than cognitive (concept of number) before being given a CTL learning; (2) There is a CTL influence on the development of language (ability of story) group $\mathrm{A}$ in the Al Khasanah Gresik Islamic Kindergarten. It is known from the difference between the ability of story before (pretest) and after (posttest) get CTL in the experimental group. Thus the second hypothesis of research stating "There is an influence CTL on the development of language in group A Al Khasanah Gresik Islamic Kindergarten" proved true. The ability to tell a story after being given a CTL model of learning is greater than the prior art skills before being given a learning model of CTL.

The suggestions in this study are as follows: (1) in learning is expected for teachers to apply CTL because many benefits are obtained such as improving the ability to speak a logical, critical, and systematic; (2) It is expected that further research can develop the CTL learning outcomes in other aspects of development, namely motor, religious and moral values, emotional social, and art; (3) It is hoped that further research can develop the results of this research by using different objects and increasing the number of research samples and using CTL method with model and system in order to obtain wider results. 


\section{References}

Depdiknas 2007, Pedoman Pengembangan Fisik/Motorik di Taman Kanak-kanak, Dikti, Jakarta.

Johnson, DW \& Johnson RT 2002, 'Cooperative Learning Methode: A Meta-Analysis', Journal of Research in Education.

Johnson, EB 2002. Contextual Teaching \& Learning Menjadikan Kegiatan Belajar-Mengajar Mengasyikkan dan Bermakna, Mizan Learning Center, Bandung.

Nurhadi, Yasin, B \& Senduk, AG 2002, Pembelajaran Kontekstual (Cooperatif Learning di Ruang-ruang Kelas), Gramedia Widiasarana, Jakarta.

Sudono, A 1995, Alat Permainan dan Sumber Belajar, Depdikbud Dirjen Dikti, Jakarta.

Sugiyono 2009, Metode Penelitian Bisnis (Pendekatan Kuantitatif, Kualitatif, dan ReD), Alfabeta, Bandung.

Sujiono, Yuliani Nurani \& Sujiono, Bambang. 2013. Bermain Kreatif Berbasis Kecerdasan Jamak. Jakarta: PT Indeks.

Sujiono, YN \& Sujiono, B 2010, Bermain Kreatif Berbasis Kecerdasan Jamak, PT Indeks, Jakarta. 